\title{
ARTICLE
}

\section{Physicochemical characterization of drinking water from borehole wells in Ulaanbaatar city, Mongolia}

\author{
Dashdondog Gerelt-Od ${ }^{1 *}$, Togtokh Enkhjargal ${ }^{1}$, Zorigt Byambasuren ${ }^{1}$ and Ganbold Dagvasuren $^{2}$ \\ ${ }^{1}$ Department of Water Resource and Water Utilization, Institute of Geography and Geoecology, \\ Mongolian Academy of Sciences, Ulaanbaatar, Mongolia \\ ${ }^{2}$ Mongolian Criminological Association, \\ Ulaanbaatar, Mongolia
}

ARTICLE INFO: Received: 9 Nov, 2020; Accepted: 31 jul, 2021

Abstract: Groundwater is the most important natural source for supplying of drinking water around the world, especially in rural areas. The $14^{\text {th }}$ khoroo (sub-district) of Khan-Uul district of Ulaanbaatar is only one khoroos where its inhabitants engage in animal husbandry and agriculture, which play an important role in the district's economic growth, faces an increasing shortage of groundwater due to population and economic growth in the agriculture sector in the sub-district. In this study, we present the hydro-chemical characteristics and spatial distribution of aquifer using GIS and multivariate statistical approaches. During the sampling periods, a total of 51 groundwater samples were collected from 46 deep wells and 5 shallow wells in the area between October and November 2019. Samples included parameters of anions and cations $\left(\mathrm{Na}^{+}, \mathrm{K}^{+}, \mathrm{Ca}^{2+}, \mathrm{Mg}^{2+}, \mathrm{Cl}^{-}, \mathrm{SO}_{4}^{2-}\right.$ , $\left.\mathrm{NO}_{3}{ }^{-}, \mathrm{HCO}_{3}^{-}\right)$and EC. Data from all the samples were subject to cluster and component analysis. As a result, three clusters were defined and it was established that the dominant groundwater type is $\mathrm{HCO}_{3}{ }^{-} \mathrm{Ca}^{2+}-\mathrm{Na}^{+}$. The parameter of $\mathrm{Mg}^{2+}$ and $\mathrm{Ca}^{2+}$ were not set in the permissible limits of the second and third clusters. Principal component analysis (PCA) illustrated that the northern part of the study area is greater affected to anthropogenic activities and aquifer mineralogy. Moreover, it found that $\mathrm{Ca}^{2+}$ and $\mathrm{Mg}^{2+}$ correlated with each other, which could be helpful in site specific monitoring of groundwater quality. The results of the study will contribute to management and quality control of the groundwater in the city.

Keywords: Hydrochemical process; Ulziit; Multivariate statistical analysis;

\section{INTRODUCTION}

Water quality analysis is one of the most important aspects in groundwater studies. Determination of physicochemical characteristics of water is essential for assessing the suitability of water for domestic, industrial and agriculture [1] use. Groundwater is a valuable source both in Ulaanbaatar, the capital city of Mongolia and throughout the rural areas.

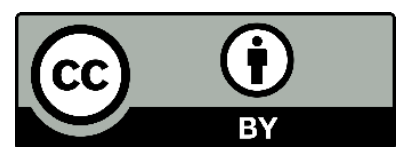

The Author(s). 2021 Open access This article is distributed under the terms of the Creative Commons Attribution 4.0 International License (https://creativecommons.org/licenses/by/4.0/), which permits unrestricted use, distribution, and reproduction in any medium, provided you give appropriate credit to the original author(s) and the source, provide a link to the Creative Commons license, and indicate if changes were made. 
Almost 46 per cent ( 1.4 million out of a total 3.2 million people) of Mongolia's population live and work in Ulaanbaatar In the city, underground water is the source of drinking water for the entire population of the capital city, nearly the entire rural population obtain their water from underground water sources. Water supply for Ulaanbaatar residents is provided by underground fresh water from a depth of 35-40 $\mathrm{m}$ in the deep pit of Tuul River [12]. The intensive and rapid pace of ongoing urbanization pose risks for the quality and composition of underground water, which is increasingly failing to meet the hygiene requirements due to environment and soil pollution caused by household waste holes (toilets and dumping of household liquid and solid wates and without centralized sewage system) in the sprawling ger districts of Ulaanbaatar that have existed for many years. In particular, natural properties of groundwater, especially its nutritional value, exchange, location, movement, and regime, as well as its quality and composition, are beginning to change as a impact of human activities, such as construction work. On the other hand, the quality of natural water that has changed as a result of these man-made impacts, in turn, negative affects our lives and economies [8]. There are reports about Ulaanbaatar's main water source, the Tuul River, being polluted. Water quality in the downstream area of the Tuul River has deteriorated due to the disposal of domestic wastewater from the capital city and communities [9] that have sprung up along the stretch of the river. The city is expected to continue to be over concentrated as the population continues to increase, as a consequence of which the city could encounter many serious environmental challenges. According to a recent study, groundwater of Ulaanbaatar is contaminated by concentration of $\mathrm{NO}_{3}$ through atmospheric deposition, fertilizers, industrial waste effluent, and improperly maintained septic systems. There are high levels of aluminum and iron in groundwater originating from inadequate storage of drinking water in the ger districts, the effect of corroded iron pipes and given the soil composition of the geographic areas [10]. However, the evaluation of groundwater resources requires an understanding of hydrogeochemical properties of the aquifer [16]. In order to evaluate the characteristics of groundwater, physicochemical parameters, as well as, hydrochemistry were studied by many researchers nationwide. A large number of groundwater studies have also focused on assessing the suitability of ground water for drinking purposes $[14,15]$.

Ulziit sub-district, which is our study area, is one of the remote and newly developed urban areas of Ulaanbatar and its water supply system is not connected to the centralized system. Households, business entities, organizations, and herder families in this urban area have been using only groundwater for drinking and domestic use. Therefore, understanding of the geochemical processes of the aquifers is necessary, but it a timedemanding process important for groundwater quality monitoring and from the perspective of sustainable water resource management. The study's objective was to examine the present status of drinking water quality in the $14^{\text {th }}$ khoroo of Khan-Uul district in Ulaanbaatar. 




Figure 1. Location map of the study area and groundwater wells

\section{MATERIALS AND METHODS}

\section{Description of the study area}

The study area, which was randomly selected, was the Ulziit sub-district at $14^{\text {th }}$ khoroo in Khan-Uul district, in the southwest of Ulaanbaatar and $28 \mathrm{~km}$ from the centre of the capital city. Ulziit sub-district has a population of approximately 5,500, where water samples for this study were collected. The sub-district. which covers a land area of 7200 hectares and, where 218 herder families live who own 11,600 heads of livestock adjacent to the Special Protected Area (SPA). Ulziit is located in Turgen valley of Bogd Khan SPA. The region consists of several aquifers, which are primarily Modern quaternary and Paleozoic fissured aquifers. The sediment consists of mainly sand, gravel, sandstone, alevrolite and conglomerate.

\section{Sampling and analytical procedure}

A total of 51 groundwater samples were collected from deep wells in the ger districts $(n=46)$, and shallow wells $(n=5)$ between October and November 2019. The depths of the wells varied from 22 to $102 \mathrm{~m}$. Prior to sampling the wells were pumped for $10 \mathrm{~min}$ until steady state chemical conditions were obtained. The samples were collected in 1-liter polyethylene (PET) bottles at 6 different locations in the $14^{\text {th }}$ khoroo of Khan-Uul district. These sample bottles were stored in an ice box, and tested at the Water Analysis Laboratory of the Institute of Geography and Geoecology, Mongolian Academy of Sciences. In order to assess the quality of ground water, we used the current Mongolian drinking water standard MNS 0900:2018, as well as relevant WHO standards. The physicochemical parameters of temperature, turbidity, $\mathrm{pH}$, electrical conductivity (EC) and total dissolved solids (TDS) were measured on the spot with calibrated portable instruments.

\section{Multivariate statistical analysis}

Multivariate statistics are useful tools to attaining significant information from hydrochemical data set in the groundwater 
system. To evaluate the analytical data, multivariate statistical techniques, i.e., correlation analysis, principal component analysis (PCA), and cluster analysis (CA) were used in this study, by using SPSS (version 26.0) software, for windows. Parametric statistical methods were also used for calculating the normal statistical and nomal quality

\section{RESULTS AND DISCUSSION}

\section{Hydrochemistry and water quality}

The results of measured parameters of groundwater samples of the study area are summarized in Table 1. The groundwater at most of the sites were predominantly slightly alkaline, the value of which ranged from 7.20 to 7.79 , with a mean value of 7.48 . This indicates that all well water samples are within the limit of 6.5-8.5 as per the National standard and WHO standard for drinking purpose. TDS has an average value of $268.7 \mathrm{mg} / \mathrm{l}$ that ranges from 152 to $691 \mathrm{mg} / \mathrm{l}$. According to WHO (2011) recommendation, TDS up to $500 \mathrm{mg} / \mathrm{l}$ is the highest desirable level, and except for the four samples (S17, S23, S45, S48) all other samples fall within the permissible limit. Subsequently, EC of the water samples ranges from 306 to $1258 \mu \mathrm{S} / \mathrm{cm}$ with a mean of $515.5 \mu \mathrm{S} / \mathrm{cm}$. The values indicate that all the samples fall within the permissible limit except two samples (S45 and S48), which exceeded the maximum allowed concentration recommended in groundwater of $1000 \mu \mathrm{S} / \mathrm{cm}$, as determined by the Mongolian standard MNS 0900:2018 and EC up to $1500 \mu \mathrm{S} / \mathrm{cm}$ WHO (2011) recommendation. Usually, drinking water which has an EC value less than $400 \mu \mathrm{S} / \mathrm{cm}$ is considered a high quality water. According to standards, the turbidity should not exceed 5 NTU. As showed in Table 1, the obtained values indicate that all water samples, except only from one sampling site (S39), had a turbidity value greater than the maximum permissible level.

Calcium concentration ranged from 29.1 to $117.2 \mathrm{mg} / \mathrm{L}$, with an average value of 57.7 $\mathrm{mg} / \mathrm{L}$. The maximum permissible level of $\mathrm{Ca}^{2+}$ in groundwater is $100 \mathrm{mg} / \mathrm{L}$ as per MNS 0900:2018 and WHO (2011), all the samples fall within the permissible limit except three parameters, i.e., the range, mean and standard deviation. Pearson's correlation matrix was used to identify the relationship among the pairs of parameters. When more than two variables were considered simultaneously, multiple linear regression analyses were used to evaluate their interdependency.

samples (S2, S45, S48). Magnesium concentration varied from 8.5 to $51.4 \mathrm{mg} / \mathrm{L}$, with an average value of $19.6 \mathrm{mg} / \mathrm{L}$. The maximum allowable limit of $\mathrm{Mg}^{2+}$ in groundwater is $30 \mathrm{mg} / \mathrm{L}$ (MNS 0900:2018) and WHO (2011), and all the samples fall within the permissible limit except for four samples (S2, $\mathrm{S} 23, \mathrm{~S} 45, \mathrm{~S} 48)$. Sodium $\left(\mathrm{Na}^{+}\right)$concentration ranged from 9.03 to $54.3 \mathrm{mg} / \mathrm{L}$. the maximum permissible limit of $\mathrm{Na}^{+}$concentration in groundwater is $200 \mathrm{mg} / \mathrm{L}$, as set by MNS 0900:2018 and WHO (2011), and all the samples fall within the permissible limit. Potassium $\left(\mathrm{K}^{+}\right)$concentration was present in very low concentrations for groundwater, varying from 0.48 to $7.20 \mathrm{mg} / \mathrm{L}$, with an average value of $1.33 \mathrm{mg} / \mathrm{L}$.

The mean value of Chloride $\left(\mathrm{Cl}^{-}\right)$is 23.99 $\mathrm{mg} / \mathrm{L}$ with ranges from 5.30 to $113.60 \mathrm{mg} / \mathrm{L}$. Maximum allowable limit of $\mathrm{Cl}^{-}$concentration in groundwater is $350 \mathrm{mg} / \mathrm{L}$, as set by MNS 0900:2018 and up to $250 \mathrm{mg} / \mathrm{L}$ as determined by WHO (2011). According to the National standard, all the samples fall within the permissible limit. The average concentration of $\mathrm{TH}, \mathrm{SO}_{4}{ }^{2-}, \mathrm{HCO}_{3}{ }^{-}$are $13.80,46.59,223.63$ $\mathrm{mg} / \mathrm{L}$ respectively, where all the samples fall within the permissible limits. But, in the case of $\mathrm{NO}_{3}{ }^{-}$one sampling site (S45) had nitrate $\mathrm{NO}_{3}{ }^{-}$ ) value greater than $50 \mathrm{mg} / \mathrm{L}$ MNS 0900:2018 and WHO (2011) recommendation. $\mathrm{NO}_{3}{ }^{-}$ derived from agricultural and industrial areas were primarily due to leaching from plant nutrients, nitrate fertilizers and domestic and industrial waste. In the case of major anions, $\mathrm{HCO}_{3}{ }^{-}$is predominant in groundwater samples, the average value of bicarbonate $\left(\mathrm{HCO}_{3}{ }^{-}\right)$is $223.63 \mathrm{mg} / \mathrm{L}$ and ranged from 158.60 to 332.50 $\mathrm{mg} / \mathrm{L}$. 
Table 1. Statistical summary of the measured parameters of collected groundwater samples

\begin{tabular}{|c|c|c|c|c|}
\hline \multirow{2}{*}{ Parameters } & \multicolumn{4}{|c|}{ Values form collected samples $(\mathrm{n}=51)$} \\
\hline & Minimum & Maximum & Mean & Std. Deviation \\
\hline $\mathrm{pH}$ & 7.20 & 7.79 & 7.48 & 0.16 \\
\hline $\mathrm{EC}(\mu \mathrm{S} / \mathrm{cm})$ & 306.00 & 1258.00 & 515.51 & 228.16 \\
\hline TDS (mg/L) & 152.00 & 691.00 & 268.67 & 131.22 \\
\hline $\mathrm{Na}^{+}(\mathrm{mg} / \mathrm{L})$ & 9.03 & 54.30 & 22.21 & 10.32 \\
\hline $\mathrm{K}^{+}(\mathrm{mg} / \mathrm{L})$ & 0.48 & 7.20 & 1.33 & 1.02 \\
\hline $\mathrm{Ca}^{2+}(\mathrm{mg} / \mathrm{L})$ & 29.10 & 117.20 & 57.69 & 21.19 \\
\hline $\mathrm{Mg}^{2+}(\mathrm{mg} / \mathrm{L})$ & 8.50 & 54.10 & 19.59 & 10.85 \\
\hline $\mathrm{CI}^{-}(\mathrm{mg} / \mathrm{L})$ & 5.30 & 113.60 & 23.99 & 22.98 \\
\hline $\mathrm{SO}_{4}{ }^{2-}(\mathrm{mg} / \mathrm{L})$ & 6.00 & 280.00 & 46.59 & 59.86 \\
\hline $\mathrm{NO}_{3}^{-}(\mathrm{mg} / \mathrm{L})$ & 0.00 & 70.00 & 12.59 & 11.55 \\
\hline $\mathrm{HCO}_{3}{ }^{-}(\mathrm{mg} / \mathrm{L})$ & 158.60 & 332.50 & 223.63 & 35.75 \\
\hline $\mathrm{T}(\mathrm{NTU})$ & 1.60 & 6.22 & 3.21 & 1.06 \\
\hline Total Hardness $(\mathrm{TH})$ & 7.37 & 32.87 & 13.80 & 6.04 \\
\hline $\mathrm{Na}+\mathrm{K}$ & 9.51 & 57.16 & 23.53 & 10.87 \\
\hline $\mathrm{Ca}+\mathrm{Mg}$ & 44.60 & 171.30 & 77.27 & 30.84 \\
\hline $\mathrm{Ca}+\mathrm{Mg} / \mathrm{Na}+\mathrm{K}$ & 1.09 & 6.62 & 3.57 & 1.14 \\
\hline
\end{tabular}

The variation of major cations $\left(\mathrm{Na}^{+}, \mathrm{K}^{+}\right.$, $\left.\mathrm{Ca}^{2+}, \mathrm{Mg}^{2+}\right)$ and anions $\left(\mathrm{HCO}_{3}{ }^{-}, \mathrm{Cl}^{-}, \mathrm{SO}_{4}{ }^{2-}\right.$, $\mathrm{NO}_{3}{ }^{-}$) in groundwater samples is illustrated in the Box and Whisker plot (Fig. 2) where $\mathrm{Ca}^{2+}$ and $\mathrm{HCO}_{3}^{-}$are the dominant cations and anions, respectively. It showed that, the order of relative abundance of major cations in the groundwater is $\mathrm{Ca}^{2+}>\mathrm{Mg}^{2+}>\mathrm{Na}^{+}+\mathrm{K}^{+}$, while the anions are $\mathrm{HCO}_{3}{ }^{-}>\mathrm{SO}_{4}{ }^{2-}>\mathrm{Cl}^{-}>\mathrm{NO}_{3}{ }^{-}$. $\mathrm{EC}$ and TDS of the groundwater samples (S17,
S45, S48) showed large percentage of contribution from $\mathrm{Ca}^{2+}, \mathrm{HCO}_{3}{ }^{-}$and $\mathrm{SO}_{4}{ }^{2-}$. Sampling sites S45, S48 and S17 in the Paleozoic fissured aquifer and quaternary sedimentary proluvial aquifer increase in minerals concentration was observed, indicating $\tan$ increase in hardness and mineralization. These aquifers consist of sandstone, alevrolite, conglomerate, sand and rockwaste.

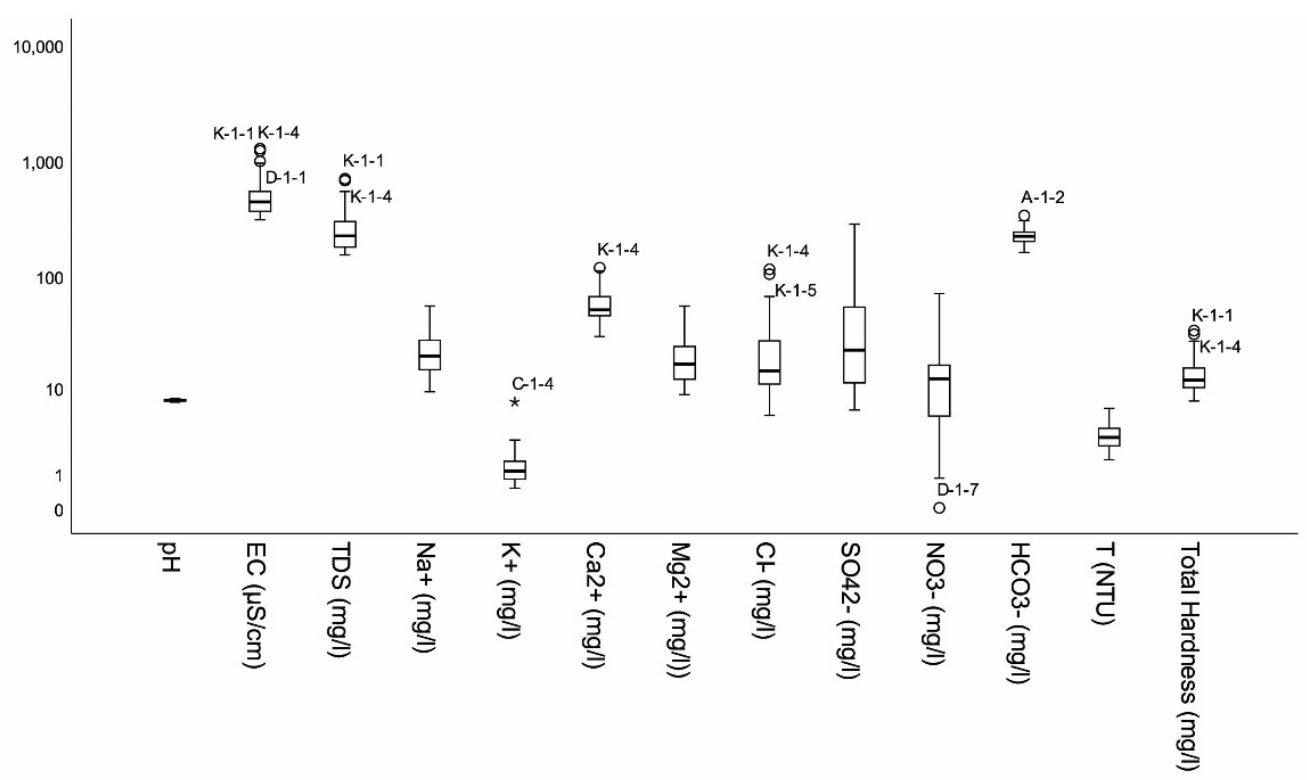

Figure 2. Box and Whisker plot showing the variation of major ion concentration of groundwater 


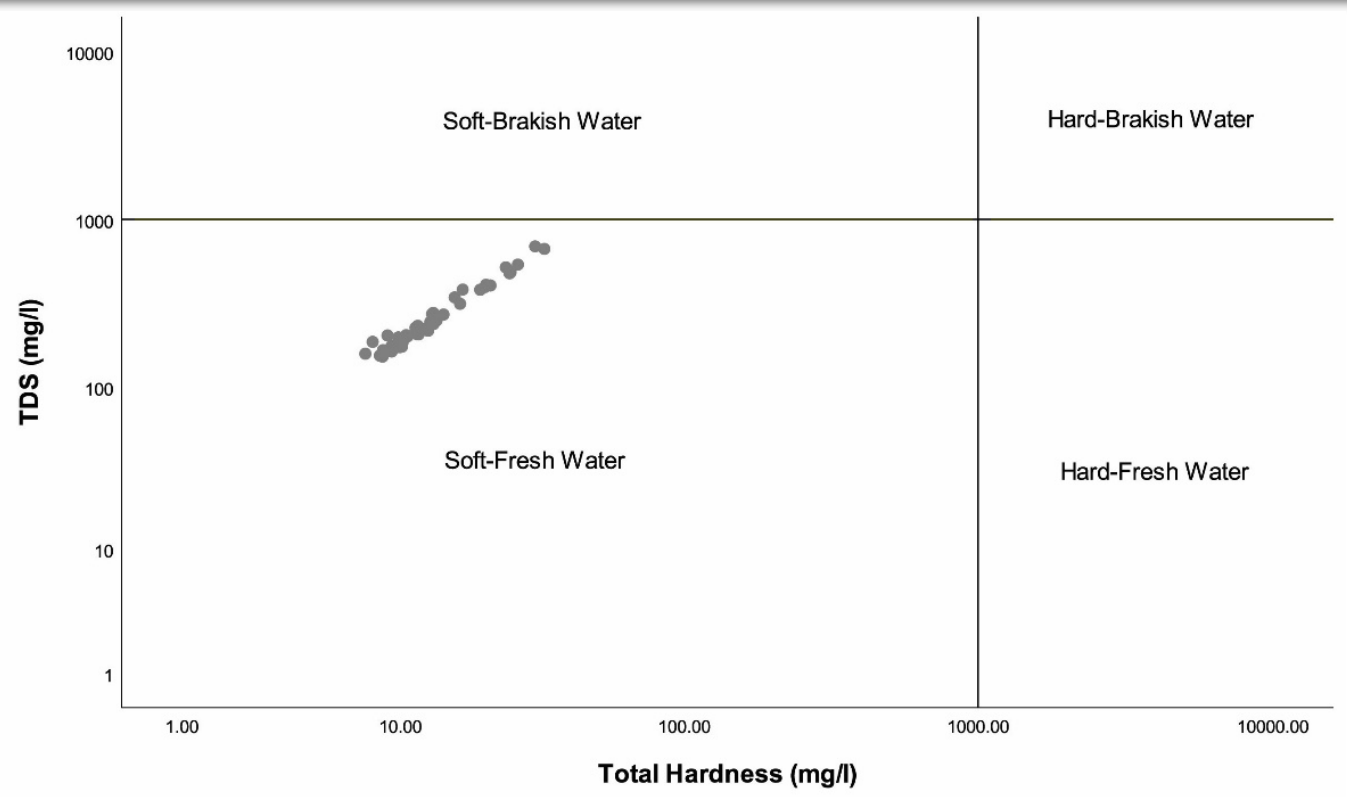

Figure 3. Groundwater quality in the study area based on TDS and TH

\section{Hydrochemical facies}

The total hardness $(\mathrm{TH})$ in $\mathrm{mg} / \mathrm{L}$ was determined by $\left(2.497 \mathrm{Ca}^{2+}+4.115 \mathrm{Mg}^{2+}\right)$, according to Todd [11]. TH in the groundwater varied from 7.37 to $32.87 \mathrm{mg} / \mathrm{L}$ with an average value of $13.80 \mathrm{mg} / \mathrm{L}$ (Table 1). Hardness of water is due to the presence of divalent metallic cations with calcium and magnesium in abundance. A detailed classification of groundwater quality based on TDS and TH (Fig. 4) shows that the majority of groundwater samples were classified under soft-fresh category.



Figure 4. Classification of groundwater types after the ion change

Dispersion of ions is represented using Piper diagram (Fig. 4). The largest anion dispersion is represented by $\mathrm{HCO}_{3}{ }^{-}$ concentration, and the $\mathrm{Ca}^{2+}$ concentration has the largest cation dispersion. Hydrochemical facies are distinct zones that possess cation and anion concentration, which help to identify the classes of water. According to the diagram, the dominant water types, which is $\mathrm{Ca}^{2+}-\mathrm{HCO}_{3}{ }^{-}$ indicates that the hydrochemistry of the groundwater samples is characterized by alkaline earths, which have excessive alkali 
metals. Most of the samples in this study belong to $\mathrm{Ca}^{2+}-\mathrm{Mg}^{2+}-\mathrm{HCO}_{3}{ }^{-}$type followed by $\mathrm{Ca}^{2+}-\mathrm{Mg}^{2+}-\mathrm{HCO}_{3}{ }^{-}-\mathrm{SO}_{4}{ }^{2-}$, respectively.

The Durov diagram is used to graphically illustrate cation and anion concentrations, related to $\mathrm{pH}$ and TDS values. From the results, ion balance diagram indicated that the most prominent water types are the $\mathrm{Ca}-\mathrm{HCO}_{3}(78 \%)$, followed by $\mathrm{Mx}-$ $\mathrm{HCO}_{3}(7.8 \%)$, in the third level by $\mathrm{Ca}-[\mathrm{Mg}]-$ $\mathrm{HCO}_{3}(3.9 \%)$, the fourth $\mathrm{Ca}-[\mathrm{Mg}]-\mathrm{SO}_{4}$ $(1.96 \%), \mathrm{Ca}-[\mathrm{Mg}]-\mathrm{HCO}_{3}-\left[\mathrm{SO}_{4}\right](1.96 \%)$ and groundwater was dominated by calcium and bicarbonate belonging to the group of $\mathrm{Ca}$ $\mathrm{HCO}_{3}$ water type.

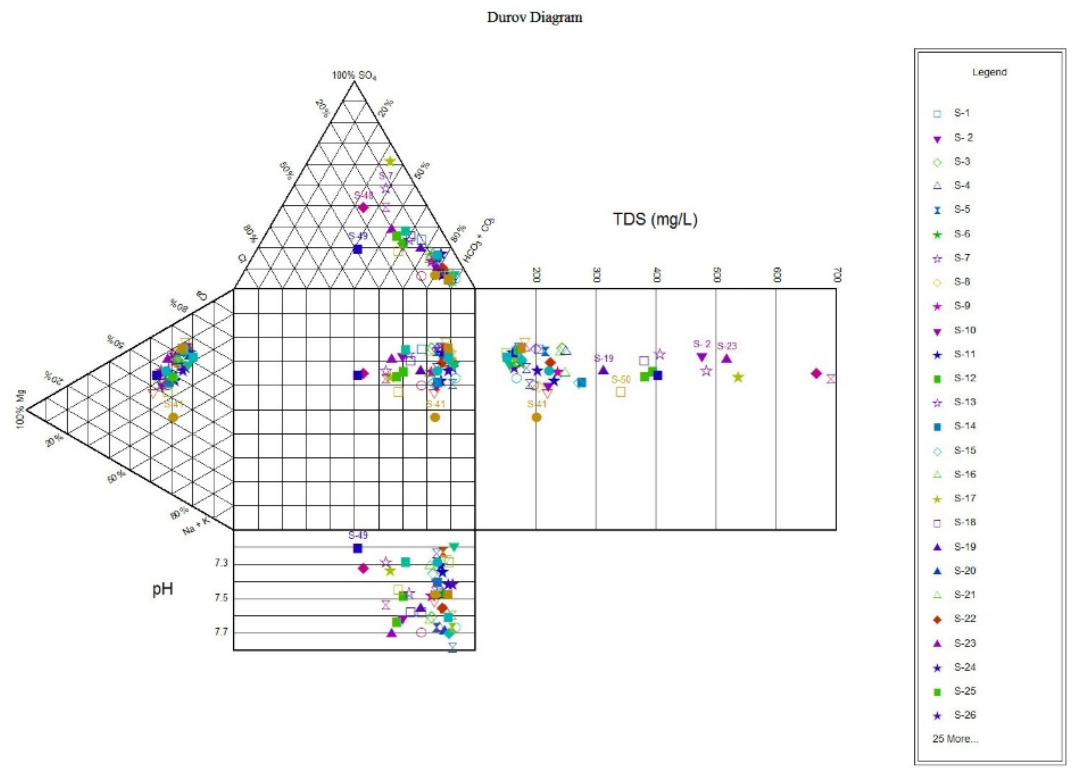

Figure 5. Chemical composition of water samples

Hydrogeochemical processes evaluation Gibbs plot was used to determine the mechanism controlling the groundwater chemistry. The measured parameters of groundwater were plotted in Gibbs diagram and it was found that the majority of samples in the study area are characterized by rock-water interactions, which are an indication of the chemical alteration of rock-forming minerals, influencing the quality of groundwater by rock dissolution, through which the water flows beneath the surface [4]. The cations and anions are derived mainly from rock weathering rather than evaporation and precipitation (Fig. 6). These may have been influenced by chemical weathering of rock forming minerals. The processes responsible for major solutes of groundwater are most likely controlled by mineral dissolution. The $\mathrm{Cl} /$ Lanions ratios of groundwater samples varied from 0.028 to 0.258 , with an average value of 0.070 (Table 3 ). In contrast, the $\mathrm{HCO}_{3} / \sum$ anion ratios ranged from 0.411 to 0.913 with an average value of 0.771. These results suggest that rock weathering, mostly silicate weathering, carbonate dissolution and evaporate dissolution are dominant in the aquifers. The rock-water interaction is a broad classification that encompasses all lithogenic influences like silicate weathering, carbonate dissolution and evaporates dissolution. 

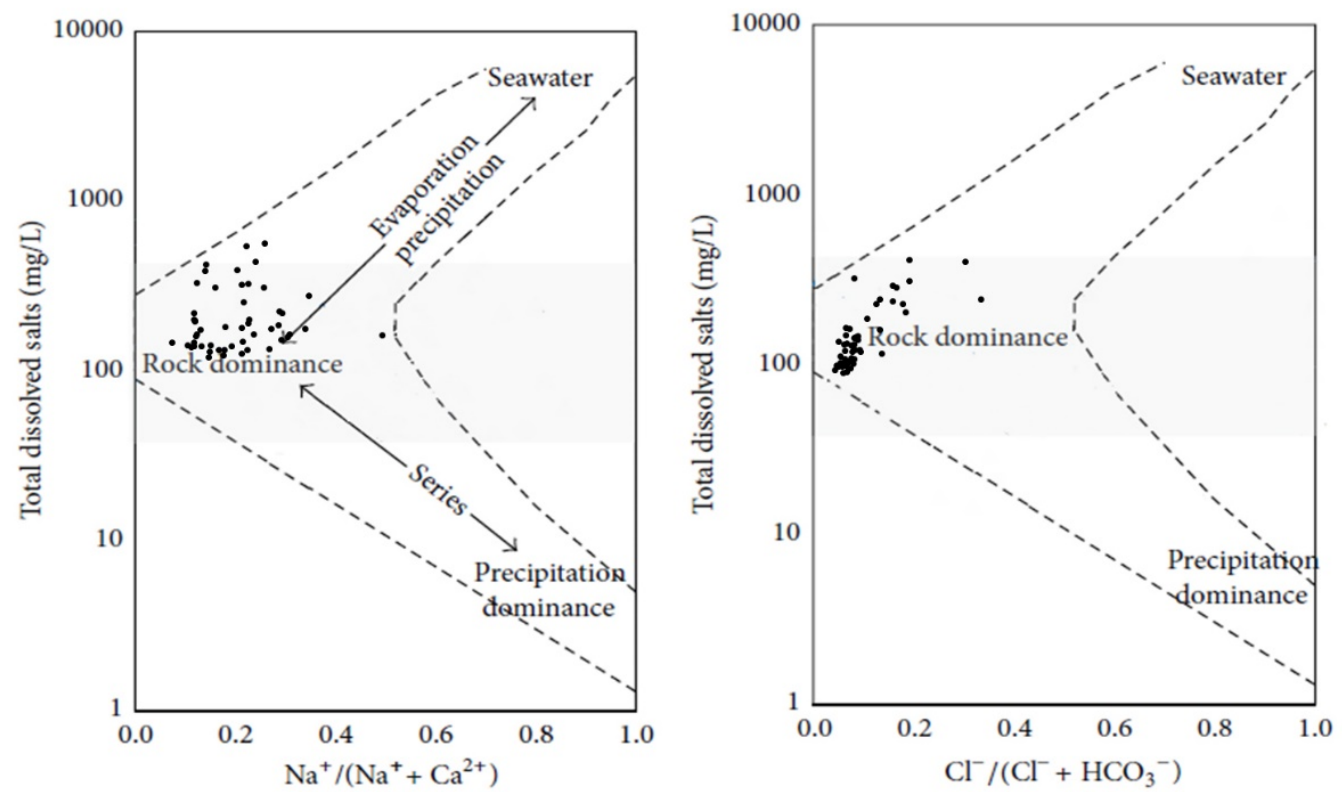

Figure 6. Gibbs plot showing the mechanisms controlling the groundwater chemistry

Table 2. Statistical summary of saturation indices (SI) of some mineral phases and rations of some chemical constituents in the groundwater

\begin{tabular}{lllll}
\hline Parameters & Minimum & Maximum & Mean & Std. Deviation \\
\hline Total Cations & 59.970 & 223.510 & 100.808 & 39.296 \\
Total Anions & 187.100 & 634.600 & 306.796 & 108.914 \\
$\mathrm{Cl} / \sum$ Anions & 0.028 & 0.258 & 0.070 & 0.042 \\
$\mathrm{HCO} / \sum$ Anions & 0.411 & 0.913 & 0.771 & 0.132 \\
$\mathrm{Na} /(\mathrm{Na}+\mathrm{Cl})$ & 0.234 & 0.750 & 0.529 & 0.120 \\
$(\mathrm{Na}+\mathrm{K}) / \mathrm{Cl}$ & 0.322 & 3.157 & 1.354 & 0.686 \\
\hline
\end{tabular}

\section{Correlation analysis}

Correlation coefficients are generally used to establish the relationship between two variables. This is an approach to demonstrate how well one variable predicts the others [4]. The Pearson's correlation matrix for the analyzed parameters of the groundwater samples is presented in Table 3. It has been observed that the correlation between EC and TDS was significantly positive $(r=996)$. The significantly positive correlation between EC and $\mathrm{Ca}, \mathrm{SO}_{4}$, TDS and $\mathrm{Mg}$ are indications that these ions are derived from the same source of water. Calcium is positively correlated with magnesium ( $\mathrm{r}=0.836)$ and the presence of magnesium in these waters might be due to silicate weathering.

\section{Principal component analysis (PCA)}

A total of 13 water quality parameters, i.e., $\mathrm{pH}, \mathrm{EC}, \mathrm{TDS}, \mathrm{Na}^{+}, \mathrm{K}^{+}, \mathrm{Ca}^{2+}, \mathrm{Mg}^{2+}, \mathrm{Cl}^{-}$, $\mathrm{SO}_{4}{ }^{2-}, \mathrm{NO}_{3}{ }^{-}, \mathrm{HCO}_{3}{ }^{-}, \mathrm{T}(\mathrm{NTU})$ and Total Hardness were analyzed by PCA for differentiating the various processes acting on the hydrogeochemistry. These parameters were grouped into 2 major PCs explaining $77 \%$ of the total variance in the data set (Table 4). The selection of variables was solely based on the eigen values $(>1)$. The performed KaiserMeyer-Olkin (KMO) test yielded a value 0.616 , which suggests that the data is eligible for performing principal component analysis. Varimax rotation was used to maximize the sum of the variance of the factor coefficients, which better explained the possible sources that influenced the water systems. 
Positive scores in PCA indicate that water samples are affected by the parameters that significantly loaded on a specific component, where as negative scores suggest that water quality is essentially unaffected by those parameters. The variances explained by the PCs are $67.031 \%$, and $10.287 \%$ for PC1, and PC4, respectively. $\mathrm{PCl}$ is heavily loaded with $\mathrm{EC}$, TDS, $\mathrm{Na}^{+}, \mathrm{Ca}^{2+}, \mathrm{Mg}^{2+}, \mathrm{Cl}^{-}, \mathrm{SO}_{4}{ }^{2-}, \mathrm{NO}_{3}{ }^{-}, \mathrm{HCO}_{3}{ }^{-}$ and Total Hardness.

Table 4. Varimax rotated principal component analysis of water quality parameters (significant values (> 0.5) are in bold type face)

\begin{tabular}{lcc}
\hline \multicolumn{1}{c}{ Parameters } & PC1 & PC2 \\
\hline $\mathrm{pH}$ & -0.008 & 0.774 \\
$\mathrm{EC}(\mu \mathrm{S} / \mathrm{cm})$ & 0.989 & -0.048 \\
$\mathrm{TDS}(\mathrm{mg} / \mathrm{l})$ & 0.988 & -0.055 \\
$\mathrm{Na}^{+}(\mathrm{mg} / \mathrm{l})$ & 0.857 & -0.159 \\
$\mathrm{~K}^{+}$ & 0.439 & -0.238 \\
$\mathrm{Ca}^{2+}(\mathrm{mg} / \mathrm{l})$ & 0.906 & 0.054 \\
$\left.\mathrm{Mg}^{2+}(\mathrm{mg} / \mathrm{l})\right)$ & 0.974 & -0.118 \\
$\mathrm{Cl}^{-}(\mathrm{mg} / \mathrm{l})$ & 0.831 & -0.056 \\
$\mathrm{SO}_{4}{ }^{2-}(\mathrm{mg} / \mathrm{l})$ & 0.878 & -0.241 \\
$\mathrm{NO}_{3}{ }^{-}(\mathrm{mg} / \mathrm{l})$ & 0.701 & 0.233 \\
$\mathrm{HCO}_{3}{ }^{-}(\mathrm{mg} / \mathrm{l})$ & 0.799 & 0.278 \\
$\mathrm{~T}(\mathrm{NTU})$ & -0.028 & 0.600 \\
$\mathrm{Total} \mathrm{Hardness}(\mathrm{mg} / \mathrm{l})$ & 0.985 & -0.048 \\
Eigen value & 8.232 & 1.242 \\
$\%$ of Variance & 63.187 & 9.687 \\
Cumulative \% & 63.187 & 72.875 \\
& & \\
\hline
\end{tabular}
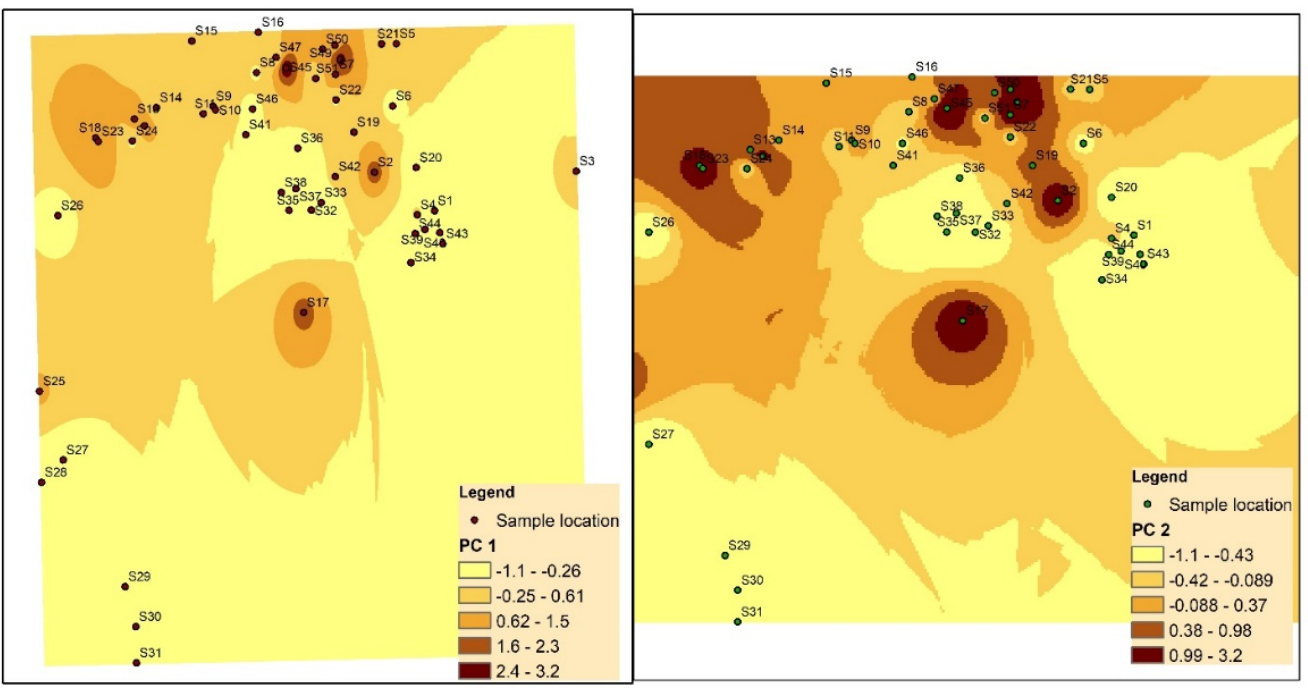

Figure 7. Spatial distribution of factor scores (PCs) (a) PC1 and (b) PC2 in the study area

CA has been used to evaluate the spatial similarities and site groupings among the sampling sites, where sampling sites belonging to a particular cluster exhibit similar characteristics with respect to the analyzed parameters. 3 major clusters were recognized from all analyzed parameters for the 51 sampling sites. 


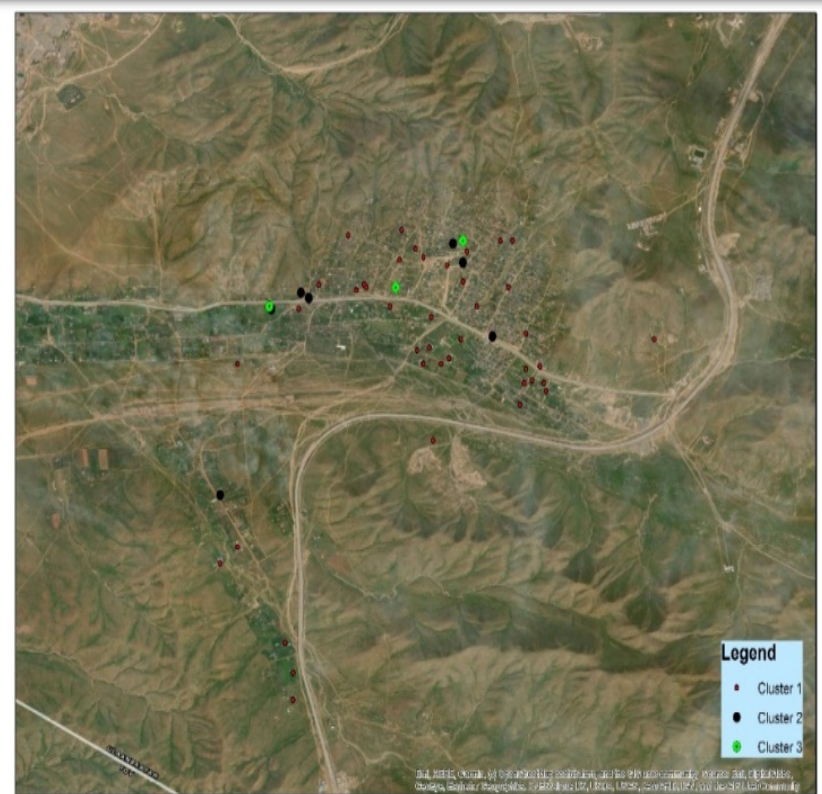

Figure 8. Cluster members of K-Means Cluster Analysis

Table 5. Mean values of chemical parameters for each cluster

\begin{tabular}{lrrr}
\hline Parameters & Cluster 1 & Cluster 2 & Cluster 3 \\
\hline $\mathrm{pH}$ & 7.48 & 7.50 & 7.40 \\
$\mathrm{EC}(\mu \mathrm{S} / \mathrm{cm})$ & 404.13 & 787.44 & 1147.67 \\
$\mathrm{TDS}($ мг/л) & 205.46 & 421.44 & 632.00 \\
$\mathrm{Na}^{+}($мГ/л) & 18.13 & 31.01 & 48.73 \\
$\mathrm{~K}^{+}($мГ/л) & 1.16 & 1.64 & 2.56 \\
$\mathrm{Ca}^{2+}(\mathrm{mg} / \mathrm{l})$ & 48.07 & 83.39 & 105.53 \\
$\left.\mathrm{Mg}^{2+}(\mathrm{mg} / \mathrm{l})\right)$ & 14.59 & 31.14 & 49.87 \\
$\mathrm{CI}-(\mathrm{mg} / \mathrm{l})$ & 13.89 & 54.06 & 65.10 \\
$\mathrm{SO} 42-(\mathrm{mg} / \mathrm{l})$ & 21.18 & 94.44 & 233.33 \\
$\mathrm{NO} 3-(\mathrm{mg} / \mathrm{l})$ & 9.16 & 19.72 & 35.67 \\
$\mathrm{HCO}-(\mathrm{mg} / \mathrm{l})$ & 211.02 & 264.70 & 264.33 \\
$\mathrm{~T}(\mathrm{NTU})$ & 3.26 & 3.17 & 2.70 \\
Total Hardness $(\mathrm{mg} / \mathrm{l})$ & 10.92 & 20.90 & 29.98 \\
\hline
\end{tabular}

\section{CONCLUSIONS}

In the present study, an attempt was made to evaluate groundwater quality of Ulziit subdistrict of $14^{\text {th }}$ khoroo, Khan-Uul district deep aquifer. Study samples included water samples from deep and shallow wells that supply water to the residents of the $14^{\text {th }}$ khoroo.

Our results indicate that both water $\mathrm{pH}$ values and $\mathrm{EC}$ of groundwater in studied area was within the standard values, indicating minimal, if any pollution. The TDS value of all the samples fall within the permissible limit except for four samples. Calcium and magnesium concentration show that the majority of samples are within the maximum permissible limit, except for three and four samples. $\mathrm{NO}_{3}{ }^{-}$in one sample ( $\left.\mathrm{S} 45\right)$ exceeded the permissible limit of (MNS 0900:2018) and WHO value $(50 \mathrm{mg} / \mathrm{l})$. The highest levels of $\mathrm{NO}_{3}{ }^{-}$were found in a sample from one household.

The predominant cation trend in $14^{\text {th }}$ khoroo aquifer is $\mathrm{Ca}^{2+}>\mathrm{Mg}^{2+}>\mathrm{Na}^{+}+\mathrm{K}^{+}$. The abundance of major anions in the $14^{\text {th }}$ khoroo deep aquifer is in the following order: $\mathrm{HCO}_{3}{ }^{-}$ $>\mathrm{SO}_{4}{ }^{2-}>\mathrm{CI}^{-}$. 
In our study, all samples of groundwater quality, based on TDS and TH, were classified as soft fresh water.

As a result, three clusters were defined and the predominating groundwater types are $\mathrm{HCO}_{3}{ }^{-}, \mathrm{Ca}^{2+}-\mathrm{Na}^{+}$. Parameter of $\mathrm{Mg}^{2+}$ and $\mathrm{Ca}^{2+}$ were not set in the permissible limits of the second and third clusters. PCA analysis illustrated that the northern part of the study area is more affected to anthropogenic activities

\section{REFERENCES}

1. Ali Obeidat, Mahmoud Alawneh., (2019), "Hydrochemistry and Groundwater Quality Assessment in Mafraq Province, Jordan”, Journal of Open Access Library, pp. 1-10.

2. Adhikary, P.P., Chandrasekharan, H., Chakraborty, D., Kumar, B., Yadv, B.R., (2009) Statistical approaches for hydrogeochemical characterization of ground water in West Delhi, India. Environ. Monit. Acces.

3. Ahmed, N., Bodrud-Doza, M., Islam, S.M.D.U., Choudry, M.A., Muhib, M.I., Zahid, A., Hossain, S., Moniruzzaman, M., Deb, N., Bhuiyan, M.A.Q Hydrogeochemical evaluation and statistical analysis of groundwater of Sylhet, north-eastern Bangladesh. Acta Geochim.

4. Bahar, M.M., Reza, M.S., 2010. Hydrochemical characteristics and quality assessment of shallow groundwater in a coastal area of Southwest Bangladesh. Environ. Earth Sci. 61, 1065-1073

5. Bodrud-Doza, M., Islam, A.R.M.T., Ahmed, F., Das, S., Saha, N., Rahman, M.S., 2016. Characterization of groundwater quality using water evaluation indices, multivariate statistics and geostatistics in central Bangladesh. Water Sci. 30 (1), 19-40.

6. Bodrud-Doza, Mohammad Amir, et al, Hydrogeochemical investigation of groundwater in Dhaka City of Bangladesh using GIS and multivariate statistical techniques, Bangladesh. and aquifer mineralogy. Moreover, it found that $\mathrm{Ca}^{2+}$ and $\mathrm{Mg}^{2+}$ correlated with each other, which could be helpful for site specific monitoring of groundwater quality. In addition, multivariate statistical analysis is one of the proper techniques to reveal hydro-chemical process and water quality.

Acknowledgements: The study was supported by the Water Services Regulatory Commission of Mongolia.

\section{Groundwater for Sustainable Development 8, 2019 (226-244).}

7. Gotelli, N.J., Ellison, A.M., 2004. A primer of ecological statistics, 1st ed. Sinauer Associates, Sunderland.

8. Javzan. Ch, 2013. Identify the impacts of ger district sewage on underground water quality and resource of Ulaanbaatar city, Ulaanbaatar, pp. 122.

9. Mohan, R., Singh, A.K., Tripathi, J.K., Chowdhary, $\quad$ G.C., 2000. Hydrochemistry and quality assessment of groundwater in Naini industrial area, Allahabad district, Uttar Pradesh. J. Geol. Soc. India 55, pp. 77-89.

10. Naranchimeg B, Enkhbayar D, Selenge G, Baldandorj M, Groundwater contamination of Ulaanbaatar city, Natural condition and territorial location aspects influencing socioeconomic development. The 4th international conference proceeding, Ulaanbaatar, pp. 367-376.

11. Oyu. Tsogtbayar, Munkhjargal B, Naranchimeg J, Mirza M. Hussain, Haider A. Khwaja (2018), Comparative Physicochemical Characterization of Drinking Water from Select Endpoints of Use and Household Storage Containers in Ulaanbaatar City, Mongolia, Central Asian Journal of Medical sciences, pp. 265-267.

12. Odontuya G., Tsiiregzen A., Boldbaatar G., Khureldavaa O., Ouyntsetseg D., Urnaa B., Amarsanaa B. (2018), Hydrochemical study of 
water supply of Ulaanbaatar city, "Природа внутренней Азии" (Nature of Inner Asia). Issue №2 (7), 2018.

13. Todd, D.K. (1980) Groundwater Hydrology. 2nd Edition, John Wiley \& Sons, New York.

14. Tuvaanjav G, (2011). Mongolian inventions and water quality issues, Ulaanbaatar, pp. 74-80.

15. Tuul River Basin Integrated water resources management assessment report (2012), pp. 175-253.
16. Umar A., Umar R., Ahmad M.S., 2001. Hydrogeological and hydrochemical framework of regional aquifer system in Kali Ganga sub-basin India. Environ. Geol. 40 (4-5).

17. Webster R., Oliver, M.A., 2007. Geostatistics for environmental scientists. Statistics in practice. Wiley, Chichester.

18. WHO, (2011). WHO guidelines for drinking-water quality, 4th Ed. World Health Organization, Geneva. 